\title{
Optimalisasi Peran Sistem Pengendalian Intern dalam Mencegah Terjadinya Penyelewengan Kas dan Aset pada Lembaga Pendidikan Non Pemerintah (Swasta)
}

\author{
Fathiyah \\ Dosen Fakultas Ekonomi Universitas Batanghari, Jambi \\ Correspondence email : fathiyah_zaky@yahoo.co.id
}

\begin{abstract}
The purpose of this study is to analyze how to optimize the role of internal control system in preventing the occurrence of fraud on cash and assets in non government or private educational institution. Tool of analyzed used in this research is internal control system according to COSO definition and combined with internal control system according to Government Regulation Number 60 Year 2008 with 5 internal control component that is; 1) Control Environment, 2) Risk Assessment, 3) Control Activity, 4) Information and Communication and 5) Monitoring. The result of the research shows that optimizing the role of the internal control system is very helpful to the management in managing the finances and assets owned so as to prevent the occurrence of fraud on the cash and assets in private educational institution. The expectation of the future by optimizing the role of internal control system on cash management and assets in non government/or the private educational institution will be more efficient and effective which will ultimately improve the quality and accountability of the private educational institution.
\end{abstract}

Keywords : Internal control system, cash, assets, COSO

\section{PENDAHULUAN}

Menurut Peraturan Pemerintah Nomor 17 tahun 2010 tentang Pengelolaan dan penyelengaraan pendidikan yang dimaksud dengan pengelolaan pendidikan adalah pengaturan kewenangan dalam penyelenggaraan sistem pendidikan nasional oleh Pemerintah, pemerintah provinsi, pemerintah kabupaten/kota, penyelenggara pendidikan yang didirikan masyarakat, dan satuan pendidikan agar proses pendidikan dapat berlangsung sesuai dengan tujuan pendidikan nasional. Tambahan penjelasan terkait Penyelengaraan pendidikan yang didirikan masyarakat disini adalah lembaga pendidikan non pemerintah atau yang dikelola oleh pihak swasta baik pada tingkat sekolah mulai dari Pendididikan Anak Usia Dini (PAUD), Taman Kanak-kanak, sekolah dasar sampai dengan sekolah lanjutan dan pada tingkat perguruan tinggi.

Tata kelola lembaga pendidikan negeri ataupun lembaga pendidikan swasta memiliki kesamaan hanya saja pada lembaga pendidikan negeri semua petunjuk teknis pelaksanaannya sudah diatur dalam undang-undang dan peraturan pemerintah seperti Juknis pengelolaan dana BOS, sedangkan pada lembaga pendidikan swasta selain dari undang-undang dan peraturan pemerintah juga tunduk pada peraturan dan kebijakan organisasi yang menaungi lembaga pendidikan tersebut dalam hal ini umumnya bentuk organisasinya adalah yayasan pendidikan. Dalam rangka meningkatkan kualitas dan akuntabilitas pada lembaga pendidikan swasta perlu adanya suatu kontrol/pengawasan dan kendali yang diterapkan seperti organisasi lainnya yaitu adanya sistem pengendalian intern, karena bila pengendalian internnya lemah dapat menimbulkan penyelewengan dalam pengambilan kebijakan oleh pimpinan, dan penyimpangan dalam pengelolaan keuangan serta aset di lembaga pendidikan tersebut. Oleh karena itu dengan dioptimalkannya peran sistem pengendalian intern dapat membangun birokrasi pendidikan yang bersih sehingga dapat mengawal kebijakan yang telah diterapkan dan menjaga aset yang dimiliki dengan baik serta mencegah terjadinya penyelewengan pada pengelolaan kas dan aset yang dimiliki oleh lembaga pendidikan tersebut.

Intinya adalah pengendalian intern merupakan alat untuk membantu pimpinan dalam melakukan tugasnya sehingga melalui pengendalian intern ini pemimpin dapat menilai struktur organisasi yang ada dan kegiatan yang telah dilakukan keseluruhanya bertujuan untuk mencegah dan menghindarkan dari terjadi kesilapan, kecurangan dan penyelewengan. Beberapa penelitian yang pernah dilakukan dan dapat menjadi acuan terkait dengan sistem pengendalian intern yaitu penelitian yang dilakukan Ismani dkk (2014) dengan lokasi penelitian pada Universitas Negeri Yogyakarta (UNY) Tahun 2014 dengan hasil penelitiannya adalah semua unsur sistem pengendalian intern pemerintah (SPIP) telah diimplentasikan dengan baik di UNY, hal 
ini mengindikasikan bahwa implementasi SPIP memiliki peranan penting dalam menunjang akuntabilitas keuangan UNY dalam mempertahankan opini Wajar Tanpa Pengecualian (WTP). Penelitian lainnya dilakukan Zamzami dkk (2015) dengan studi kasus pada sebuah perguruan tinggi negeri memberikan kesimpulan dari hasil penelitiannya adalah temuan penelitian mengindikasikan bahwa elemen-elemen sistem pengendalian internal yang diaplikasikan oleh PTN X cukup efektif dan mendukung praktek manajerial yang baik.

Penelitian berikutnya dilakukan Irawan (2016) yang meneliliti tentang pengaruh penerapan Sistem Pengendalian Intern (SPIP) terhadap pencegahan Fraud pengelolaan Dana Bantuan Operasional Sekolah (Dana BOS) pada Sekolah Dasar di Kecamatan Andir Kota Bandung, hasil penelitiannya menunjukkan bahwa Peran SPIP berpengaruh terhadap Fraud pengelolaan Dana BOS. Hasil uji Determinasi menunjukkan bahwa 49,6\% pencegahan Fraud dipengaruhi oleh SPIP dan 50,4\% dipengaruhi oleh Faktor lainnya. Penerapan pengendalian intern pada lembaga pendidikan swasta seharusnya lebih efektif dibandingkan pada lembaga pendidikan negeri mengingat semua pendanaan operasional perguruan tinggi dibebankan pada organisasi itu sendiri tanpa adanya bantuan pendanaan dari pemerintah pusat atau daerah sehingga pengawasan pengelolaan keuangan terutama pada kas dan asetnya harus lebih ketat lagi, namun sering kita melihat, mendengar dan membaca munculnya beberapa kasus di televisi, koran dan internet tentang korupsi yang terjadi di beberapa lembaga pendidikan negeri seperti misalnya penyalahgunaan kebijakan oleh kepala sekolah dan pimpinan perguruan tinggi negeri, penggelapan uang oleh oknum karyawan yang bekerja pada bagian pengelolaan keuangan dan penyelewengan penggunaan asset sekolah dan kampus seperti laptop, kipas angin,dan Air Conditioner (AC) misalnya oleh karyawan yang diberi kepercayaan memegang aset tersebut, dalam hal ini aset seperti ini biasanya digunakan untuk keperluan pribadi dan tidak mau mengembalikan jika aset tersebut akan ditarik oleh pihak sekolah ataupun kampus dan dari pihak sekolah atau kampus sendiri tidak bisa berbuat banyak, hal seperti ini mengindikasikan bahwa peran sistem pengendalian intern pada lembaga pendidikan tersebut belum berjalan secara optimal.

Contoh kasus lainnya yang sering terjadi dibanyak organisasi oleh oknum pegawai tidak terkecuali di lembaga pendidikan negeri ataupun swasta antara lain pertanggungjawaban atas penggunaan dana kegiatan yang sudah dilaksanakan seringkali tidak dilaporkan kepada pimpinan, dan yang tidak habis fikir lagi oleh oknum pegawai yang melaksanakan kegiatan tersebut merasa tidak bersalah serta menganggap uang yang disetorkan ke rekening sekolah atau kampus dianggap mutlak milik sekolah atau kampus sehingga tidak perlu pertanggungjawaban kepada pimpinan diatasnya. Indikasi yang seperti ini berpotensi untuk menjadi salah satu celah yang bisa menyebabkan timbulnya penyelewengan pada kas. Berdasarkan dari penjelasan dan beberapa kasus yang pernah terjadi seperti diatas, maka penulis mencoba untuk meneliti bagaimana mengoptimalkan peran sistem pengendalian intern di lingkungan lembaga pendidikan swasta dalam mencegah terjadinya penyelewengan pada kas dan aset yang dimiliki sehingga kas serta aset pada lembaga pendidikan tersebut menjadi aman dan dapat terjaga dengan baik dengan tujuan akhirnya adalah peningkatan kualitas dan akuntabilitas lembaga pendidikan dimaksud. Tujuan penelitian ini adalah untuk mengoptimalkan peran sistem pengendalian intern di lingkungan lembaga pendidikan non pemerintah (swasta) dalam mencegah terjadinya penyelewengan pada kas dan aset yang dimiliki oleh lembaga pendidikan tersebut.

\section{Kerangka Teoritis}

Definisi Pengendalian Intern Menurut The Committee of Sponsoring Organization (COSO) dalam buku COSO Based Auditing yang disusun Tunggal (2000) pengendalian intern adalah suatu proses yang dijalankan oleh dewan komisaris, manajemen, dan personil lain yang didisain untuk memberikan keyakinan memadai tentang pencapaian tiga kelompok tujuan yaitu (1) efektivitas dan efisiensi operasi, (2) Keandalan laporan keuangan dan, (3) Kepatuhan terhadap hukum dan peraturan yang berlaku. Sedangkan menurut Mulyadi (2001) defenisi dari pengendalian intern adalah :

1. Menjaga kekayaan organisasi, Jika sistem pengendalian intern berjalan baik maka dapat mengantisipasi terjadinya kecurangan, pemborosan, ketidakefisienan dan penyalahgunaan terhadap aktiva perusahaan. 
2. Mengecek ketelitian dan keandalan akuntansi, keandalan data/informasi akuntansi digunakan oleh manajemen dalam pengambilan keputusan untuk meningkatkan ketelitian dan dapat dipercayanya data akuntansi

3. Mendorong efisiensi, Kebijakan perusahaan mampu memberikan manfaat tertentu dengan memantau setiap pengorbanan yang telah dikeluarkan guna mendapatkan hasil yang sebaik-baiknya.

4. Mendorong dipatuhinya kebijakan manajemen, untuk mencapai tujuan perusahaan maka kebijakan, prosedur, sistem pengendalian intern yang dirancang untuk memberikan keyakinan yang memadai bahwa kebijakan, prosedur yang ditetapkan perusahaan akan dipatuhi oleh seluruh karyawan.

Menurut Jusuf (2001) Sistem Pengendalian Intern yang dirancang dengan baik akan dapat mendorong ditetapkannya kebijakan manajemen. Selain itu juga mendorong terciptanya efisiensi operasi, melindungi aktiva perusahaan dari pemborosan, kecurangan dan pencurian serta menjamin terciptanya data akuntansi yang tepat dan dapat dipercaya. Ada 7 prinsip pengendalian intern yang pokok meliputi :

1. Penetapan tanggung jawab yang jelas, untuk menciptakan pengendalian intern yang baik manajemen harus menetapkan tanggung jawab secara jelas dan tiap orang memiliki tanggung jawab untuk tugas yang diberikan kepadanya.

2. Penyelenggaraan catatan yang memadai, Untuk melindungi aktiva dan menjamin semua karyawan melaksanakan prosedur yang ditetapkan diperlukan pencatatan yang baik. Catatan yang bisa dipercaya akan menjadi sumber informasi yang digunakan manajemen untuk memonitor perusahaan.

3. Pengasuransian kekayaan dan karyawan perusahaan, kekayaan perusahaan harus diasuransikan dengan jumlah yang memadai, demikian juga karyawan yang menangani kas dan surat-surat berharga, cara ini dilakukan untuk mengurangi pencurian terhadap kas.

4. Pemisahan pencatatan dan penyimpanan aktiva, Pegawai yang menyimpan atau bertanggungjawab atas aktiva tertentu tidak diperkenankan mengurusi catatan akuntansi aktiva yang bersangkutan.

5. Pemisahan tanggung jawab atas transaksi yang berkaitan, pertanggung jawaban atas transaksi yang berkaitan atau bagian-bagian dari transaksi yang berkaitan harus ditetapkan pada orang-orang atau bagian-bagian dalam perusahaan, sehingga pekerjaan yang dilakukan oleh seseorang akan dicek/diperiksa oleh orang lain.

6. Penggunaan peralatan mekanis, Sebaiknya menggunakan peralatan mekanis untuk mencatat setiap transaksi keuangan.

7. Pelaksanaan pemeriksaan secara independen, walaupun sistem pengendalian intern sudah dirancang dengan baik penyimpangan mungkin bias terjadi sepanjang waktu, oleh karena itu perlu dilakukan pengkajian ulang secara teratur, untuk memastikan bahwa prosedur telah diikuti dengan benar. Pengkajian ulang ini biasanya dilakukan oleh pihak ektern dan dilakukan evaluasi secara menyeluruh apakah sudah efektifkah sisitim pengendalaian intern pada perusahaan.

Menurut Hartadi (1999) untuk mencapai tujuan pengendalian akuntansi suatu sistem harus memenuhi enam prinsip dasar pengendalian intern yang meliputi :

1. Pemisahan fungsi, tujuannya adalah untuk menghindari dan pengawasan segera atas kesalahan atau ketidakberesan. Adanya pemisahan fungsi untuk dapat mencapai suatu efisiensi dari pelaksanaan tugas

2. Prosedur pemberian wewenang, tujuannya adalah untuk menjamin bahwa transaksi telah diotorisir oleh orang yang berwenang

3. Prosedur akuntansi, Dokumentasi yang layak penting untuk menciptakan sistem pengendalian akuntansi yang efektif

4. Prosedur dan catatan akuntansi, tujuannya adalah agar dapat disiapkan catatan-catatan akuntansi yang teliti secara cepat dan dilaporkan kepada pihak yang menggunakan secara tepat waktu

5. Pengawasan fisik, berhubungan dengan penggunaan alat-alat mekanis dan elektronik dalam pelaksanaan dan pencatatan akuntansi

6. Pemeriksaan Intern secara bebas, menyangkut pembanding antara catatan aset dengan aset yang betulbetul ada, menyelenggarakan rekening-rekening kontrol dan mengadakan perhitungan kembali penerimaan dan pengeluaran kas. Tujuannya adalah untuk pengendalian pengawasan data.

Sistem pengendalian intern berfungsi sebagai pedoman penyelenggaraan dan tolak ukur pengujian efektivitas. Menurut COSO (Tunggal, 2000) ada 5 komponen sistem pengendalian intern yaitu : 
1. Lingkungan pengendalian,

Terdiri dari tindakan, kebijakan, dan prosedur yang menggambarkan sikap manajemen puncak, direksi dan pemilih suatu entitas tentang pengendalian intern dan pentingnya bagi entitas. Lingkungan pengendalian intern membentuk fondasi untuk keempat komponen pengendalian yang lain. Ketiadaan satu atau lebih unsur yang penting dari lingkungan pengendalian akan menyebabkan sistem tidak efektif.

2. Penaksiran resiko

Penaksiran resiko suatu entitas untuk pelaporan keuangan merupakan identifikasi, analisis, dan pengelolaan resiko-resiko yang relevan terhadap penyusunan laporan keuangan yang secara wajar disajikan sesuai dengan prinsip-prinsip akuntansi yang berlaku umum. Proses penaksiran resiko harus mempertimbangkan kejadian dan keadaan ektern dan intern yang mungkin timbul dan secara tidak baik mempengaruhi kemampuan entitas untuk mencatat, mengolah, mengikhtisarkan, dan melaporkan data keuangan dengan asersi manajemen dalam laporan keuangan.

3. Aktivitas pengendalian

Aktivitas pengendalian merupakan kebijakan dan prosedur yang membantu meyakinkan bahwa tindakan yang diperlukan diambil untuk menghadapi resiko-resiko yang tersangkut dalam mencapai tujuan entitas.

4. Pemrosesan informasi dan komunikasi

Sistem informasi yang relevan terhadap tujuan pelaporan keuangan yang meliputi sistem akuntansi, terdiri dari metode dan catatan yang ditetapkan untuk mencatat, mengolah, mengikhtisarkan, dan melaporkan transaksi suatu entitas dan mempertahankan akuntabilitas untuk aktiva dan utang yang berkaitan.

5. Pemantauan.

Untuk memberi kepastian yang memadai bahwa tujuan suatu entitas dapat tercapai, manajemen harus memonitor pengendalian intern untuk menentukan apakah pengendalian beroperasi seperti yang diinginkan dan pengendalian intern dimodifikasi agar sesuai dengan perubahan dalam berbagai kondisi.

Sebagai pembanding dari unsur pengendalian intern menurut COSO diatas adalah unsur pengendalian intern berdasarkan Peraturan Pemerintah Nomor 60 Tahun 2008 tentang Sistem pengendalian Intern Pemerintah yaitu pengendalian intern yang sering dipraktekkan di lingkungan pemerintah diberbagai negara meliputi :

1. Lingkungan Pengendalian

Pimpinan Instansi Pemerintah dan seluruh pegawai harus menciptakan dan memelihara lingkungan dalam keseluruhan organisasi yang menimbulkan perilaku positif dan mendukung terhadap pengendalian intern dan manajemen yang sehat.

2. Penilaian resiko

Pengendalian Intern harus memberikan penilaian atas resiko yang dihadapi unit organisasi baik dari luar maupun dari dalam

3. Kegiatan pengendalian

Kegiatan pengendalian membantu memastikan bahwa arahan pimpinan Instansi Pemerintah dilaksanakan. Kegiatan pengendalian harus efisien dan efektif dalam pencapaian tujuan organisasi.

4. Informasi dan komunikasi

Informasi harus dicatat dan dilaporkan kepada pimpinan Instansi pemerintah dan pihak yang ditentukan. Informasi disajikan dalam bentuk sarana tertentu serta tepat waktu sehingga memungkinkan pimpinan Instansi Pemerintah melaksanakan pengendalian dan tanggung jawabnya.

5. Pemantauan

Pemantauan harus dapat menilai kualitas kinerja dari waktu ke waktu dan memastikan bahwa rekomendasi hasil audit dan reviu lainnya dapat segera ditindaklanjuti.

6. Adapun lingkup kerja sistem pengendalian intern menurut Wiwoho (2017) dalam makalah beliau yang disampaikan pada Forum Satuan Pengawas Internal (SPI) Nasional III PTN di Jayapura adalah ruang lingkup pelaksanaan tugas kepengawasan SPI di PTN adalah non akademik dan akademik yang berimplikasi pada aspek keuangan, aset dan SDM/kepegawaian melalui kegiatan pengawasan yang 
meliputi : (1) Audit : Audit kinerja, audit keuangan dan audit tujuan tertentu, (2) Reviu, (3) Pemantauan,

(4) Evaluasi, dan (5) Fasilitasi.

Jika dilihat dari proses/tahapan SPI terdapat 5 ruang lingkup pelaksanaan tugas SPI, yaitu pemeriksaan intern terhadap (1) Perencanaan dan penganggaran, (2) Pelaksanaan anggaran, (3) Pelaporan Keuangan, (4) Pelaksanaan tugas pejabat perbendaharaan, dan (5) Program pengendalian gratifikasi. Sedangkan kompetensi keahlian yang harus dimiliki anggota SPI yaitu (1) Akuntansi/ keuangan, (2) Manajemen sumber daya manusia, (3) Manajemen Aset, (4) Hukum, dan (5) Ketatalaksanaan.

\section{METODE PENELITIAN}

Metode yang dipakai dalam penelitian ini adalah metode kualitatif dengan melihat kasus atau permasalahan yang terjadi dan dibandingkan dengan teori yang ada kemudian dianalisis untuk mendapatkan hasil dan kesimpulan. (Adisetiawan dan Yunan, 2016; Adisetiawan, 2017; Asmas dkk, 2018)

\section{HASIL DAN PEMBAHASAN}

Sistem pengendalian intern bertujuan untuk mencapai pengelolaan keuangan yang efektif, efisien, transparan dan akuntabel. Keberadaan sistem pengendalian intern sangat penting bagi suatu institusi karena pengendalian intern yang lemah akan mengakibatkan kerugian, skandal, kegagalan, bahkan kebangkrutan atau rusaknya reputasi. Jika resiko dibiarkan saja tanpa adanya media pengendali resiko, maka hal tersebut akan menjadi permasalahan institusi dalam mecapai tujuannya (Picket, 2003). Berdasarkan hasil analisis terhadap kasus-kasus yang pernah muncul seperti diatas dapat disimpulkan bahwa untuk menguatkan peran sistem pengendalian intern yang sudah ada dengan mengacu pada definisi COSO dan Peraturan Pemerintah Nomor 60 Tahun 2008 dengan meggunakan 5 unsur/komponen sistem pengendalian intern sebagai berikut:

1. Lingkungan Pengendalian

Optimalisasi pengendalian intern pada komponen ini antara lain seperti ; a) sudah sesuaikah struktur organisasi yang dibentuk dengan jumlah pegawai dan kebutuhannya, b) Apakah uraian pekerjaan setiap personil sudah efektif atau belum, c) Bagaimana dengan fungsi audit internnya apakah sudah berjalan dengan optimal atau tidak dan d) Bagaimana dengan kompetensi Sumber Daya Manusia yang ada apakah sudah baik atau masih rendah. Beberapa kebijakan yang dapat dilakukan oleh lembaga pendidikan tersebut untuk mengoptimalkan peran sistem pengendalian intern yang ada yaitu dengan mendata kembali berapa jumlah pegawai yang ada dan menseleksi personil-personil yang ada berdasarkan kompetensi dan kebutuhan organisasi sehingga setiap personil memahami apa yang menjadi bidang pekerjaan dan tanggung jawabnya, dan yang paling penting adalah adanya uraian tugas yang jelas beserta standar prosedurnya. Fungsi audit intern juga harus di optimalkan dan yang paling penting untuk menjadi perhatian adalah penguatan personil yang bertugas di lingkup pengendalian intern perguruan tinggi sesuai dengan kompetensi yang dimiliki yaitu keahlian keuangan/akuntansi, Manajemen sumber daya manusia, manajemen aset, hukum dan ketatalaksanaan.

2. Penaksiran Resiko

Penguatan sistem pengendalian intern pada komponen ini antara lain seperti a) Personil/pegawai yang bisa memahami bagaimana mengindentifikasi resiko dan, b) Tanggap terhadap sistem informasi yang baru atau perubahan resiko yang terjadi secara tiba-tiba yang terkait dengan sistem pengendalian intern. Beberapa kebijakan yang dapat dilakukan oleh lembaga pendidikan swasta dalam mengoptimalkan peran sistem pengendalian intern yang ada adalah dengan memberikan pelatihan kepada personil/pegawai terkait dengan pelatihan mengenai identifikasi resiko, mengenali sumber resiko dan menggali jenis informasi dalam mengolah resiko seperti informasi keuangan, informasi dokumen dan informasi kontrak-kontrak terkait. Dan yang tak kalah penting adalah pimpinan telah menetapkan prosedur dalam menganalisis resiko serta mencari pengendalian yang tepat dalam meminimalisir dan mencegah terjadinya resiko tersebut.

3. Aktivitas Pengendalian

Optimalisasi peran sistem pengendalian intern pada kompenen ini antara lain seperti a) Apakah reviu terhadap kinerja keuangan, anggaran dan operasional kegiatan sudah optimal atau belum b) Apakah pembinaan terhadap sumber daya manuasia dan kompetensi sudah memadai atau belum, c) Apakah 
Pengamanan fisik aktiva seperti perhitungan aktiva berkala, perhitungan persediaan dengan membandingkan dengan catatan pengendalian sudah optimal atau belum, dan d) Bagaimana dengan pemisahan fungsi otorisasi transaksi, pencatatan transaksi dan penyimpanan aktiva sudah optimalkah atau belum. Dengan melihat unsur-unsur yang ada pada komponen sistem pengendalian intern diatas dapat dikatakan bahwa komponen ini yang paling rawan terjadinya penyelewengan dan kebocoran karena menyangkut dengan penganggaran dan pencatatan aktiva sehingga perlu penguatan ekstra pada komponen tersebut. Penguatan peran sistem pengendalian intern yang dapat dilakukan pada komponen ini agar penyelewengan kas dan aset lainnya dapat dicegah yaitu dengan rutin melakukan reviu terhadap kinerja keuangan dan kegiatan yang sudah dilaksanakan setiap semester. Menyusun anggaran berikut dengan rincian dan menyusun standar harga/biaya sehingga resiko terjadinya kecurangan dan penyelewengan anggaran/kas dapat diatasi. Satu hal yang paling krusial dalam melindungi aset yang ada adalah pemisahan fungsi terhadap personil yang mengelola aset seperti personil yang mencatat dan yang memegang aset harus orang yang berbeda dan setiap orang bisa saling mengcroschek pekerjaannya sehingga jika terjadi kecurangan dan penyelewengan terhadap aset dapat dihindari. Dari semua kebijakan yang sudah disebutkan tadi yang paling penting adalah meningkatkan kompetensi sumber daya manusia yang mengelola keuangan dan aset sehingga jika kompentesi personil yang mengelola aset baik maka semua yang menjadi kekayaan dan aset pada lembaga pendidikan tersebut dapat terpelihara dengan baik serta terlindungi dengan aman.

4. Informasi dan Komunikasi

Penguatan peran sistem pengendalian intern pada komponen ini antara lain seperti; a) Apakah pengolahan informasi yang terkait dengan pelaporan keuangan sudah berjalam optimal atau belum , b) Apakah sudah ada perangkat lunak khusus yang mendukung dalam mengolah data keuangan untuk penyusunan laporan keuangan, c) apakah sudah ada buku pedoman dan prosedur yang terkait operasionalisasi pekerjaan pegawai atau belum. Resiko yang akan muncul apabila tidak ada perangkat aplikasi khusus yang terkait dengan sistem pelaporan keuangan pada lembaga pendidikan akan menyebabkan penyusunan laporan keuangan masih dilakukan secara manual sehingga waktu yang diperlukan dalam menyusun laporan keuangan menjadi lebih lama. Resiko berikutnya yang muncul adalah jika lembaga pendidikan belum menetapkan aturan pedoman yang terkait dengan operasionalisasi pekerjaan pegawai dapat menyebabkan ada beberapa karyawan yang harus melakukan pekerjaan yang banyak jumlahnya tetapi ada sebagian pegawai yang lebih banyak santainya daripada bekerja hal ini meyebabkan terjadinya ketidak efisienan dan pemborosan biaya serta waktu Kebijakan pengendalian intern yang dapat dilakukan pada komponen ini adalah dengan menggandeng pihak ketiga yang menawarkan aplikasi khusus sistem pelaporan keuangan lembaga pendidikan sehingga laporan keuangan dapat disusun lebih akurat dan bisa menghemat waktu serta biaya. Disamping itu pihak manajemen lembaga pendidikan harus secepatnya menyusun pedoman dan prosedur standar operasional pegawai sehingga setiap pegawai mengetahui dan memahami apa yang menjadi pekerjaannya dan dampaknya pekerjaan dapat diselesaikan dengan tepat waktu serta memenuhi azas keadilan bahwa setiap orang mempunyai beban kerja yang sama sehingga jika semua personil bekerja sesuai standar dan prosedur yang ditetapkan akan menghemat biaya dan waktu yang ada.

5. Pemantauan

Penguatan peran sistem pengendalian intern pada komponen ini antara lain seperti ; a) Apakah pengawasan secara lansung dan melekat oleh atasan lansung khususnya yang terkait dengan keuangan sudah optimal atau belum, b) Apakah pelaksanaan audit internal sudah optimal atau belum, c) Bagaimanakah kelengkapan data yang tercatat dalam informas keuangan dengan asset fisiknya sudah optimalkah ?, d) Apakah sudah ada pelaksanaan pemeriksaan audit secara independen.

Apabila pengendalian intern pada unsur ini lemah dapat menyebabkan rawan terjadinya kecurangan dan penyelewengan terutama pada kas dan aset lainnya karena kurangnya pengawasan dari atasan lansung sehingga membuat pegawai bisa berbuat sesuka hati terhadap dana dan aset yang digunakan serta merasa sedang tidak diawasi, catatan yang belum lengkap terhadap aset juga turut berperan memperburuk kondisi yang terjadi. Walaupun pengendalian intern sudah dilaksanakan pada suatu organisasi dengan baik namun tidak menutup kemungkinan terjadinya kecurangan, hal ini bisa saja terjadi karena kelalaian dari unsur 
pimpinan dalam pelaksanaan kegiatan ataupun dari pegawai yang tidak mempunyai rasa memiliki dan tanggung jawab penuh pada pekerjaannya dan organisasi tersebut. Kebijakan yang dapat dilakukan untuk mengoptimalkan peran sistem pengendalian intern pada komponen ini adalah rutin untuk terus melakukan evaluasi minimal setiap semester baik pada kinerja pegawai, keuangan dan aset. Pimpinan lansung memberikan penekanan kepada pegawai bahwa setiap pegawai mempunyai tanggung jawab penuh atas pekerjaaannya dan akan ada punihsment jika terjadi pelanggaran. Ada reviu dari hasil evaluasi yang sudah dilakukan sehingga bisa segera dilakukan perbaikan, dan yang terakhir jika memungkinkan ada audit yang dilakukan dari pihak eksternal sehingga evaluasi secara meyeluruh dapat dilaksanakan dan kedepannya peran sistem pengendalian intern lebih optimal, efisien dan efektif sehingga dapat meningkatkan kualitas dan akuntabilitas lembaga pendidikan tersebut kedepannya.

\section{SIMPULAN}

1. Peran sistem pengendalian intern pada lembaga pendidikan swasta sangat membantu pihak manajemen dalam mengelola keuangan dan aset pada lembaga pendidikan tersebut sehingga dapat mencegah terjadinya penyelewengan pada kas dan aset yang dimiliki oleh lembaga pendidikan dimaksud.

2. Optimalisasi peran sistem pengendalian intern tersebut diatas dilakukan dengan mengacu pada sistem pengendalian intern menurut defenisi COSO yang dikombinasikan dengan Peraturan Pemerintah Nomor 60 Tahun 2008 tentang Pengendalian Intern Pemerintah dengan menggunakan 5 komponen sistem pengendalian intern yaitu : a) Lingkungan pengendalian, b) Penaksiran resiko, c) Aktivitas pengendalian, d) Informasi dan komunikasi, dan e) Pemantauan.

\section{DAFTAR PUSTAKA}

Adisetiawan, R., and Yunan Surono, 2016, Indonesia Capital Market Efficiency, British Journal of Economics, Finance and Management Sciences, 11(1), 108-121

Adisetiawan, R., 2017, Does Stock Option Force Bid-Ask Spread and Abnormal Return?, International Research Journal of Finance and Economics, (161), 96-104

Asmas., Denny, Hasminidiarty, dan Adisetiawan, 2018, Struktur Modal dan Variabel yang Mempengaruhinya, JMAS (Jurnal Manajemen dan Sains), 3(2), 237-250

Hartadi, Bambang, 1999, Sistem Pengendalian dalam Hubungan dengan Manajemen dan Audit, Edisi Ketiga, BPFE Yogyakarta

Ismani, Andian Ari Istiningrum, Adhi Nugroho, dan Adeng Pustikaningsih, 2014, Implementasi Sistem Pengendalian Intern di Universitas Negeri Yogyakarta, Jurnal Economica, 10(1)

Irawan, S, 2016, Pengaruh Penerapan Sistem Pengendalian Intern Pemerintah (SPIP) terhadap Pencegahan Fraud Pengelolaan Dana Bantuan Operasional Sekolah (Studi pada Sekolah Dasar di Kecamatan Andir Kota Bandung, Skripsi, Universitas Pasundan Bandung

Jusuf, Al Haryono, 2001, Dasar-dasar Akuntansi Jilid 2, Edisi keenam, STIE YKPN Yogyakarta

Mulyadi, 2001, Sistem Akuntansi, Edisi Ketiga, Salemba Empat, Jakarta

Picket, KHS, 2003, The Essential Hand Book of Internal Auditing, Second Edition, John Wiley and Sons Inc, West Sussex

Peraturan Pemerintah Nomor 60 Tahun 2008 tentang Sistem Pengendalian Intern Pemerintah

Peraturan Pemerintah Nomor 17 Tahun 2010 tentang Pengelolaan dan Penyelenggaraan Pendidikan

Tunggal, Amin Widjaya, 2000, COSO-Based Auditing, Harvarindo, Jakarta

Wiwoho, Jamal, 2017, Peran SPI dalam Meningkatkan Tata Kelola Perguruan Tinggi, Makalah disampaikan pada Forum Satuan Pengawas Internal (SPI) Nasional III PTN di Hotel Aston, Jayapura, 19 - 21 April 2017.

Zamzami, Faiz dan Ihda Arifin Faiz, 2015, Evaluasi Implementasi Sistem Pengendalian Internal : Studi Kasus pada Sebuah Perguruan Tinggi Negeri, Jurnal Akuntansi Multiparadigma, 6(1) 